\title{
In situ and genetic characterization of Gossypium barbadense populations from the states of Pará and Amapá, Brazil
}

\author{
Vanessa Cavalcante de Almeida(1), Lúcia Vieira Hoffmann(1), Gilberto Ken It Yokomizo(2), \\ Joaquim Nunes da Costa ${ }^{(1)}$, Marc Giband ${ }^{(3)}$ and Paulo Augusto Vianna Barroso(1)
}

\begin{abstract}
(1)Embrapa Algodão, Caixa Postal 174, CEP 58428-095 Campina Grande, PB, Brazil. E-mail: vancalmeida@hotmail.com, hoff@cnpa.embrapa.br, jnunes@cnpa.embrapa.br, pbarroso@cnpa.embrapa.br (2)Embrapa Amapá, Caixa Postal 10, CEP 68903-419 Macapá, AP, Brazil. E-mail: gilbertoyokomizo@yahoo.com.br ${ }^{(3)}$ Centre de Coopération Internationale en Recherche Agronomique pour le Développement (Cirad-Bios), Unité Mixte de Recherche, Développement et Amélioration des Plantes, Avenue Agropolis, 34398 Montepellier Cedex 5 , France. E-mail: giband@cnpa.embrapa.br
\end{abstract}

\begin{abstract}
The objective of this work was to characterize the populations of Gossypium barbadense in the states of Amapá and Pará, Brazil. In situ characterization was conducted through interviews with the owners of the plants and environmental observations. Leaf or petal tissue as well as seed samples were collected for genetic characterization by single sequence repeats markers and for storage in germplasm banks, respectively. The plants were maintained in dooryards and used mainly for medical purposes. The genetic analysis showed no heterozygous plants at the loci tested $(f=1)$, indicating that reproduction occurs mainly through selfing. The total genetic diversity was high $\left(\mathrm{H}_{\mathrm{e}}=0.39\right)$; and a high level of differentiation was observed between cotton plants from the two states $\left(\mathrm{F}_{\mathrm{ST}}=0.36\right)$. Conventional methods of in situ maintenance of $G$. barbadense populations are not applicable. The conservation of the genetic variability of populations present in the two states could be achieved through germplasm collection and establishing of ex situ seed banks.
\end{abstract}

Index term: cotton, genetic diversity, germplasm, SSR markers.

\section{Caracterização in situ e genética de Gossypium barbadense dos Estados do Pará e do Amapá}

Resumo - O objetivo deste trabalho foi caracterizar populações de Gossypium barbadense dos estados do Amapá e Pará. A caracterização in situ foi conduzida por meio de entrevistas com os proprietários das plantas e por observações sobre o ambiente. Tecidos de folhas ou de pétalas, além de sementes, foram coletados para a caracterização genética com marcadores SSR ("single sequence repeats") e para o armazenamento em bancos de germoplasma, respectivamente. As plantas eram mantidas em fundos de quintal e usadas, principalmente, para fins medicinais. As análises genéticas não mostraram plantas heterozigotas nos locos testados $(f=1), \mathrm{o}$ que indica que a reprodução ocorre principalmente por meio de autofecundação. A diversidade genética total foi alta $\left(\mathrm{H}_{\mathrm{e}}=0,39\right)$, e um alto nível de diferenciação foi observado entre as plantas de algodoeiro dos dois estados $\left(\mathrm{F}_{\mathrm{ST}}=0,36\right)$. Métodos convencionais para a manutenção in situ das populações de G. barbadense não são aplicáveis. A conservação da variabilidade genética das populações presentes nos dois estados deve ser realizada pela coleta de germoplasma e pela constituição de bancos de sementes ex situ.

Termos para indexação: algodoeiro, diversidade genética, germoplasma, marcadores SSR.

\section{Introduction}

Gossypium barbadense L. is an allotetraploid $\left[2 \mathrm{n}=4 \mathrm{x}=52,(\mathrm{AD})_{2}\right.$ genome $]$ cotton species native from North of Peru, and are widely distributed in Brazil (Brubaker et al., 1999; Barroso \& Freire, 2003). Two types of this cotton species are found in Brazil. The first one corresponds to cultivars introduced mainly from the United States and Israel, for extra-long lint production. The planted area is small, occupying less than $0.5 \%$ of cotton area in the country. The other type is represented by traditional genotypes that have not suffered any kind of conventional breeding and descend from cotton plants cultivated by local people, before the European colonization (Neves et al., 1968; Freire, 2000). Nowadays, G. barbadense can be found over almost all the Brazilian territory and, although it is not native from Brazil, the country is considered an important secondary center of cotton diversity. 
The traditional types of $G$. barbadense belong to two botanical races, both present as semi-domesticated forms (Freire, 2000). The brasiliense race was domesticated in the Amazonian basin. Seeds from each locule adhere to each other, forming a structure known as kidney-seed. Since the kidney-seed trait is determined by one major recessive gene (Turcotte \& Percy, 1990), Brubaker et al. (1999) considered it more appropriate to classify the brasiliense race as a domesticated local form. The other race (barbadense) has nonaggregated seeds and is popularly known as "quebradinho". Both races grow as shrubs and are perennials (Freire, 2000). G. barbadense was largely cultivated in Brazil, during the colonial period, to supply local spinning industry as well as for export to Europe. Its use as a fiber plant declined after Upland cotton (G. hirsutum var. latifolium) and Mocó cotton (G. hirsutum var. marie-galante) were introduced (Neves et al., 1968). The higher yields and better lint quality of both exotic cottons caused a slow and gradual substitution of G. barbadense in the Northeast and Southeast regions of Brazil.

The number of plants maintained in situ declined after this variety had lost its agricultural importance, and as a consequence, a process of the reduction of in situ genetic variability of $G$. barbadense is probably in course. The diversity that exists in Brazil is not satisfactorily represented in germplasm banks, and efforts for increasing the collections have taken place since 2004. The task of germplasm diversity conservation can be made more suitable and efficient if the conditions of in situ conservation and if the genetic structure of the populations are known.

The objective of this work was to characterize the populations of $G$. barbadense in the states of Amapá and Pará, Brazil.

\section{Materials and Methods}

Collection trips were carried out, in November 2004, to find and characterize G. barbadense and other cotton plants in the states of Pará and Amapá, Brazil. Plants were sampled at 180 points, distributed in 21 municipalities in Pará and at 117 points of nine municipalities in Amapá (Table 1). More detailed information can be accessed in the Algodões Brasileiros Nativos e Naturalizados - Albrana database (www.cnpa.embrapa.br/albrana). Information about the plants were obtained through interviews with the owners, guides and farmers, and through the analysis of the environment in which the plants were located. Data regarding the geographical coordinates, type of property, number of plants per collection point, species, type of population, seed shape, leaf color, height and age of the plants were recorded. Leaf or petal tissue as well as seed samples were collected for genetic characterization and for the storage in germplasm banks, respectively.

For genetic characterization, a total of 141 G. barbadenseplants, 84 ofthem fromeightmunicipalities of Pará state and 57 from eight municipalities of Amapá state, were evaluated with SSR markers.

The DNA from leaf or petal tissues was extracted and purified using a modified CTAB method (Ferreira \& Grattapaglia, 1998). The DNA was quantified in $0.8 \%(\mathrm{w} / \mathrm{v})$ agarose gels by comparison with known quantities of the lambda phage DNA.

SSR markers were amplified in PCR reactions containing: $1 \mathrm{X}$ PCR buffer $\left(10 \mathrm{mmol} \mathrm{L}^{-1}\right.$ Tris- $\mathrm{HCl}$, $\mathrm{pH} 8.3,50 \mathrm{mmol} \mathrm{L}^{-1} \mathrm{KCl}$ and $0.1 \%$ of Triton $\mathrm{X}-100$ ), $0.2 \mathrm{mmol} \mathrm{L}^{-1} \mathrm{dNTP}, 1$ unit Taq DNA polymerase, $2 \mathrm{mmol} \mathrm{L}^{-1}$ of each forward and reverse primer and

Table 1. Species and number of plants of Gossypium sp. collected in Pará (PA) and Amapá (AP) states, Brazil.

\begin{tabular}{lcc}
\hline Municipality and state & № of plants & Species \\
\hline Abaetuba, PA & 11 & G. barbadense \\
Aurora do Pará, PA & 1 & G. barbadense \\
Benevides, PA & 4 & G. barbadense \\
Bonito, PA & 4 & G. barbadense \\
Bragança, PA & $12 / 3$ & G. barbadense/G. hirsutum \\
Capanema, PA & 17 & G. barbadense \\
Capitão Poço, PA & 33 & G. barbadense \\
Castanha, PA & 1 & G. barbadense \\
Garrafão do Norte, PA & 12 & G. barbadense \\
Ipixuna do Pará, PA & 3 & G. barbadense \\
Irituia, PA & 10 & G. barbadense \\
Marituba, PA & 3 & G. barbadense \\
Moju, PA & $8 / 1$ & G. barbadense/G. hirsutum \\
Mãe do Rio, PA & 4 & G. barbadense \\
Ourém, PA & 9 & G. barbadense \\
Paragominas, PA & 10 & G. barbadense \\
Santa Maria do Pará, PA & 2 & G. barbadense \\
São Caetano de Odivelas, PA & 1 & G. barbadense \\
São Miguel do Guamá, PA & 3 & G. barbadense \\
Terra Alta, PA & 3 & G. barbadense \\
Tracateúa, PA & $22 / 5$ & G. barbadense/G. hirsutum \\
Amapá, AP & 21 & G. barbadense \\
Calçoene, AP & 13 & G. barbadense \\
Ferreira Gomes, AP & 10 & G. barbadense \\
Macapá, AP & 25 & G. barbadense \\
Pedra Branca do Amapari, AP & 18 & G. barbadense \\
Porto Grande, AP & 17 & G. barbadense \\
Pracuúba, AP & 10 & G. barbadense \\
Serra do Navio, AP & 2 & G. barbadense \\
Tartarugalzinho, AP & & \\
& & G. barbadense/G. hirsutum \\
\hline
\end{tabular}


$25 \mathrm{ng}$ genomic DNA, in a total volume of $20 \mu \mathrm{L}$. The final $\mathrm{MgCl}_{2}$ concentration (ranging from 2 to $4 \mathrm{mmol} \mathrm{L}{ }^{-1}$ ) was adjusted according to the primers used. The following 12 pairs of primers were used: CIR169, CIR148, CIR246, CIR372, CIR381, CIR228, CIR222, CIR272, CIR187, CIR203, BNL1414 and BNL3103 (Liu et al., 2000; Nguyen et al., 2004).

PCR reactions using CIR primers were carried out using an initial denaturation step at $94^{\circ} \mathrm{C}$ for $5 \mathrm{~min}$, followed by 35 cycles of the following: $94^{\circ} \mathrm{C}$ for $30 \mathrm{~s}$, annealing temperature according to the primer pair $\left(46^{\circ} \mathrm{C}\right.$ to $\left.55^{\circ} \mathrm{C}\right)$ for $1 \mathrm{~min}$ and $72^{\circ} \mathrm{C}$ for $1 \mathrm{~min}$. A final extension step at $72^{\circ} \mathrm{C}$ for 8 min was performed. Amplifications with the BNL primers were performed using an initial denaturation step at $95^{\circ} \mathrm{C}$ for $12 \mathrm{~min}$, followed by 30 cycles of the following: $93^{\circ} \mathrm{C}$ for $1 \mathrm{~min}, 55^{\circ} \mathrm{C}$ for $2 \mathrm{~min}$, and $72^{\circ} \mathrm{C}$ for $3 \mathrm{~min}$, with a final extension step at $72^{\circ} \mathrm{C}$ for $7 \mathrm{~min}$. The amplification products were separated on a $6 \%$ denaturing polyacrylamide gel. After the electrophoresis, the gels were stained with silver nitrate (Creste et al., 2001).

Allelic data were used to estimate the percentage of polymorphic loci, number of alleles per locus, observed heterozygosity $\left(\mathrm{H}_{\mathrm{o}}\right)$ and Nei (1978) unbiased expected heterozygosity $\left(\mathrm{H}_{\mathrm{e}}\right)$. The genetic structure was determined using Weir and Cockerham approach to F-Statistics (Weir \& Cockerham, 1984). The genetic diversity $\left(\mathrm{H}_{\mathrm{e}}\right)$ and Nei's genetic distance (Nei, 1978) were estimated for groups of plants collected in each municipality; and the variability structure was used to construct a dendrogram using the unweighted pair group method with arithmetic mean (UPGMA). The analysis was performed using the GDA program (Lewis \& Zaykin, 2009).

\section{Results and Discussion}

In both Pará and Amapá states, the great majority of the plants found belonged to the species G. barbadense (Table 1). The only two G. hirsutum plants, collected in Amapá, were found in Tartarugalzinho municipality, and were brought from the state of Maranhão by immigrants. In the state of Pará, five G. hirsutum plants were found in the municipality of Tracuateúa, three in Bragança and one in Moju, all of them from unknown origin. All plants of G. hirsutum were of the variety marie-galante and were probably brought from the Northeastern states of Brazil by human immigrants.

Gossypium specimens were mainly found in dooryards, as previously observed in the state of Mato Grosso (Barroso et al., 2005), in Mexico (Ulloa et al., 2006), in Peru and in Ecuador (Schwendiman et al., 1986; Westengen et al., 2005). In Amapá, only one plant was collected in a roadside, and three plants - present in vacant lots - were classified as spontaneous. In vacant lots, the seed dispersal was probably mediated by human activity, since discarded cotton plant material could be found in all the lots. No spontaneous plants were found in Pará, and just four roadside plants could be found. The owners cited four different uses of cotton plants. The less frequent was the ornamental use, with just one plant in Pará. The use of the lint to produce wick and to make cleanings and asepses, in the same way as cotton lint sold in the drugstores, were the third and second more frequent uses reported, respectively. Almost all plants were maintained in the dooryard for medicinal purposes, in both states, while their use to produce textile goods was not documented.

Some plant owners declared that their mother or grandmother used to spin and weave $G$. barbadense lint in the past, at least 20 years ago, but the ease with which industrialized textile garments can be acquired eliminated these traditional activities. As in the case of textile handicraft, the use of cotton for medicinal purposes is also slowly but gradually being abandoned, mainly due to the expansion of the public medical assistance.

The plants from the two states were similar in almost all the attributes evaluated, but they had different frequencies for two morphologic traits: seed type and leaf color. In the state of Pará, plants with the kidneyseed trait were prevalent (74\%), and a higher proportion of plants had red leaves (41\%). In the state of Amapá, seed-free plants predominated $(71 \%)$, and the proportion of plants with red leaves was lower (7\%). The seed type allows characterizing the $G$. barbadense race: connected or kidney-seeds determine the brasiliense race, while loose seeds characterize the barbadense race. The predominance of kidney-seed plants and the great proportion of individuals with red leaves in Pará state were associated with a higher incidence of these plants use for medicinal purposes. The attribution of more intense medicinal properties to the kidney- 
seed cotton was also mentioned in other places of Brazil (Neves et al., 1968; Barroso et al., 2005). The inhabitants of Amapá state did not associate specific morphological trait with a higher medicinal value, and the most frequent opinion was that all G. barbadense plants had similar medicinal qualities.

No G. barbadense plants were found in natural environments in any of the two states. Surveys failed to localize any such individual, and the reports from local residents agreed with the absence of plants in non-anthropic environments. Few wild populations of G. barbadense were described only in Peru and Ecuador (Schwendiman et al., 1986), origin center of the species. In other countries, where it was introduced, including Brazil, the species is reported as human-associated. Therefore, the creation of reserves, or any other form of in situ conventional conservation, is not applicable. Due to the reduction in the number of plants maintained by the local population as dooryard plants, the long-term preservation of the existent genetic diversity will rely on the constitution of ex situ germplasm banks.

The 12 pairs of primers used in this study amplified 15 loci, 13 of which were polymorphic, while two were monomorphic. The two populations showed the same percentage of polymorphic loci $(87 \%)$, and the plants from Pará had a higher number of alleles per locus. The mean number of alleles per locus was 2.53 (Table 2). This value is greater than the obtained for G. mustelinum, a rare and endemic cotton native to the Northeast region of Brazil, for wich only $1.5 \%$ alleles were amplified per locus (Batista, 2005); and similar to that observed in a representative set of Upland cotton cultivars ( $G$. hirsutum var. latifolium), cultivated in Brazil and in lines from Embrapa's cotton breeding program (Bertini et al., 2005; Menezes et al., 2008). Five exclusive alleles from plants collected in Pará state and three exclusive alleles from plants from the Amapá state were amplified and

Table 2. Percentage of polymorphic loci $\left(\mathrm{L}_{\mathrm{p}}\right)$, exclusive alleles, mean number of alleles per polymorphic locus $\left(\mathrm{N}_{\mathrm{P}}\right)$, mean observed heterozygosity $\left(\mathrm{H}_{\mathrm{o}}\right)$, mean expected heterozygosity or genetic diversity $\left(\mathrm{H}_{\mathrm{e}}\right)$, proportion of the diversity among populations $\left(\mathrm{F}_{\mathrm{ST}}\right)$ and inbreeding coefficient (f) of Gossypium barbadense, according to the state of collection.

\begin{tabular}{lccccccc}
\hline State & $\mathrm{L}_{\mathrm{p}}$ & Exclusive alleles & $\mathrm{N}_{\mathrm{P}}$ & $\mathrm{H}_{\mathrm{o}}$ & $\mathrm{H}_{\mathrm{e}}$ & $\mathrm{F}_{\mathrm{ST}}$ & $f$ \\
\hline Pará & 87 & 5 & 2.33 & 0.0 & 0.44 & 0.243 & 1.0 \\
Amapá & 87 & 3 & 2.20 & 0.0 & 0.32 & 0.082 & 1.0 \\
\hline Total & 87 & 8 & 2.53 & 0.0 & 0.39 & 0.360 & 1.0 \\
\hline
\end{tabular}

represented $20.5 \%$ of the total number of amplified alleles. Such an elevated number of exclusive alleles was also observed in G. mustelinum (Barroso et al., 2005). The high proportion of exclusive alleles is an indication that cotton plants from the two states are isolated genetically, and that the level of gene flow among G. barbadense from Pará and Amapá is low.

The observed heterozygosity was zero in both states, which resulted in a fixation or inbreeding index equal to 1 (Table 2). The lack of heterozygosity demonstrates that the plants are multiplied by self-pollination. Cotton does not have any complete self-incompatibility system, and a high level of self-pollination is usually observed in such plants. Nevertheless, cotton plants have large and attractive flowers to pollinators. Flower-visiting insect species have been described in Brazil (Pires et al., 2006; Silva, 2007), particularly bees. Thus, an even low level of heterozygosity, as reported by Lacape et al. (2007), would be expected in a natural setting, and the absence of heterozygous plants cannot solely be explained by the reproductive system of the species. The most probable reason for the absence of heterozygosity in the populations studied is the physical isolation of these plants, which are maintained in situ. In the present study, plants were found in small numbers, usually one to two plants at each collection point, and these points were distant from each other. Furthermore, physical barriers, such as houses and walls, which may hamper pollinator movement, separated the properties where cotton plants were found. Thus, the reproductive behavior of the species and the setting in which the plants are found explain the lack of heterozygosity in all plants and loci evaluated.

This assumption was further supported by the study of the genetic diversity in the populations. The total genetic diversity was found to be high $\left(\mathrm{H}_{\mathrm{e}}=0.39\right)$, indicating an elevated variability in the populations (Table 2). The diversity within states accounted for most of the variability, even though diversity between them was high, accounting for $36 \%$ of the total genetic diversity. This high value, estimated using molecular markers, is in agreement with the results obtained using morphologic markers, particularly in seed type and leaf color, which were quite different among plants from the two states. The clustering analysis, based on the municipality 
in which cotton was collected (Figure 1), confirmed the divergence between cottons deriving from states of Pará and Amapá. Two well-defined clusters were formed, one containing plants from Pará state and other from Amapá state. The relatively high value of genetic diversity between states has direct consequences on conservation strategies. It is not possible to prioritize conservation of cotton plants from one state over the ones from the other. Efforts should be made so that cotton from both states would be properly represented in germplasm banks.

The decomposition of the diversity within each state showed that the proportion of variability between cotton plants collected in different cities of Pará state is high $\left(\mathrm{F}_{\mathrm{ST}}=0.243\right)$, while in Amapá state it is only moderate $\left(\mathrm{F}_{\mathrm{ST}}=0.082\right)$ (Table 2$)$. In Amapá state, cotton plants collected at the municipalities of Amapá and Tartarugalzinho had the greatest diversity. Among plants from Pará state, those from
Bragança and Garrafão do Norte had the maximum and minimum diversity, respectively (Figura 1). The genetic differences observed in populations from both states suggest specific collection and ex situ conservation strategies. For Pará state, the strategy should consist in collecting and safeguarding a small number of individuals from a higher number of locations, while for Amapá state, collection surveys could be made in a smaller number of municipalities, in which a great number of plants should be sampled.

As in other regions outside the center of origin, G. barbadense apparently did not occur in natural environments, neither in the state of Pará nor in Amapá. Therefore, the creation of reserves, parks or areas of environmental preservation are not applicable to the species conservation. For adequate achievement of the in situ conservation of the genetic variability

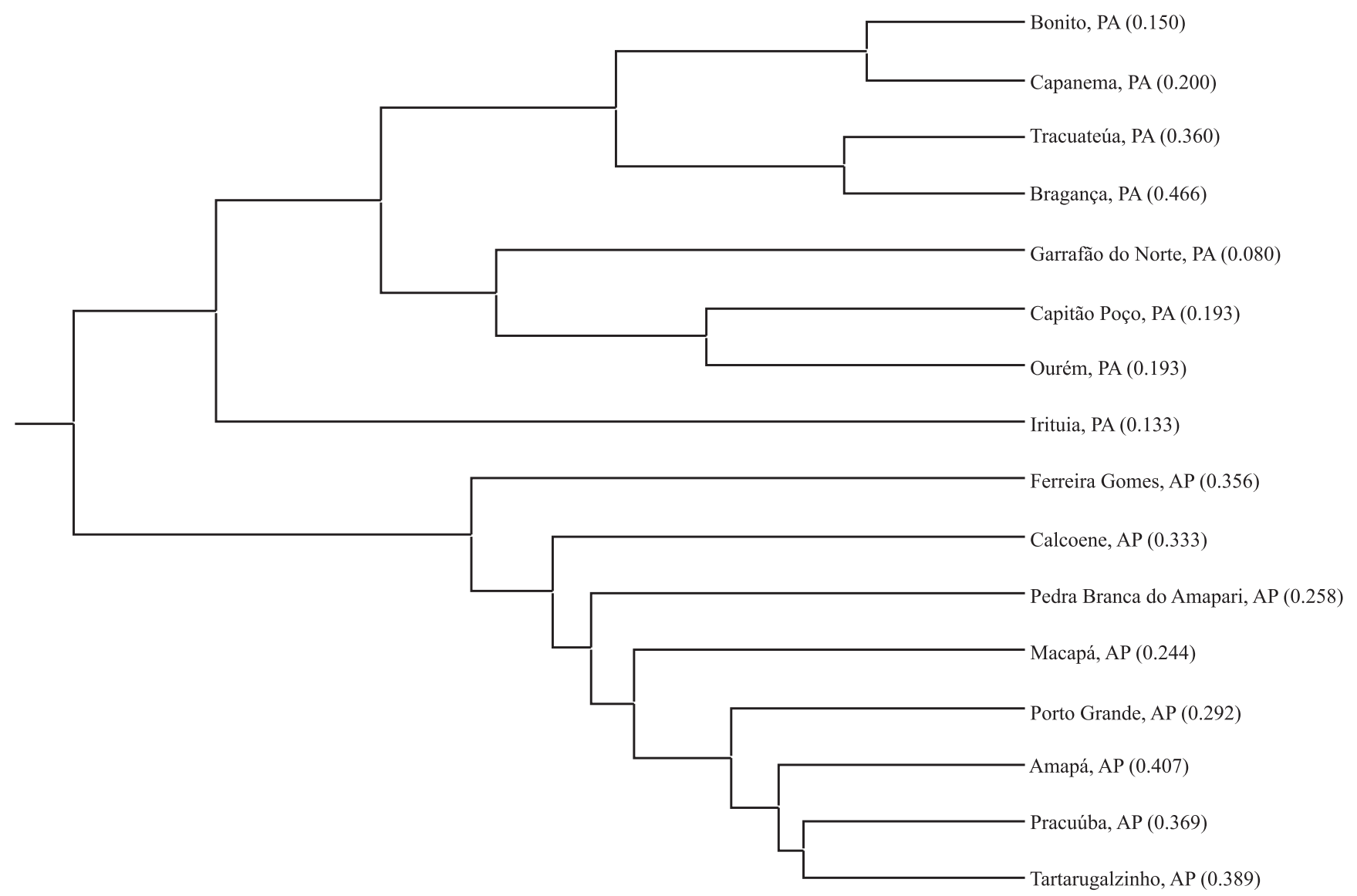

Figure 1. Dendrogram using the unweighted pair group method with arithmetic mean cluster analyses of Nei's genetics distance for Gossypium barbadense populations among municipalities of Pará and Amapá states. The values in parentheses are the mean genetic diversity of plants collected in the respective municipality. 
it would be necessary to recognize the popular knowledge and to value the products generated from these cottons both under the economical and cultural points of view. Due to difficulties for in situ conservation of genetic variability of the species, and in view of the evidences of losses in diversity already occurring among G. barbadense in both states, preservation in germplasm banks (ex situ) is the best guarantee for long-term preservation of the genetic diversity still found among G. barbadense accessions from Amapá and Pará states.

\section{Conclusions}

1. Gossypium barbadense is the most widespread cotton species in Pará and Amapá states, and it is maintained as dooryard plant for medicinal use.

2. G. barbadense plants present in both states reproduce mainly by self-pollination.

3 . There are accentuated genetic differences among G. barbadense plants from Pará and Amapá states.

4. The conservation of the genetic resources of G. barbadense present in both states should be achieved through germplasm collection and establishing ex situ germplasm bank.

\section{Acknowledgements}

To Projeto para a Conservação e Uso Sustentável da Diversidade Biológica Brasileira and to Ministério da Agricultura, Pecuária e Abastecimento, for financial support. To Francisco Alves and Fábia Lima Pinto, for technical assistance.

\section{References}

BARROSO,P.A.V.; COSTA, J.N.; CIAMPI,A.Y.; RANGEL,L.E.P.; HOFFMANN, L.V. Caracterização in situ de populações de G. barbadense do Estado do Mato Grosso. Campina Grande: Embrapa Algodão, 2005. 8p. (Comunicado Técnico, 244).

BARROSO, P.A.V.; FREIRE, E.C. Fluxo gênico em algodão no Brasil. In: PIRES, C.S.S.; FONTES, E.M.G.; SUJII, E.R. (Ed.). Impacto ecológico de plantas geneticamente modificadas: o algodão resistente a insetos como estudo de caso. Brasília: Embrapa Recursos Genéticos e Biotecnologia: CNPq, 2003. p.163-193.

BATISTA, C.E.A. Conservação, diversidade e estrutura genética de populações de Gossipium mustelinum presente no semiárido Nordestino, 2005, 54p. Monografia - Universidade Estadual da Paraíba, Campina Grande.
BERTINI, C.H.C. de M.; SCHUSTER, I.; SEDIYAMA, T.; BARROS, E.G. de; MOREIRA, M.A. Analysis of cotton genetic diversity by microsatellites and pedigree. Crop Breeding and Applied Biotechnology, v.5, p.369-378, 2005.

BRUBAKER, C.L.; BOURLAND, F.M.; WENDEL, J.F. The origin and domestication of cotton. In: SMITH, C.W.; COTHEN, J.T. (Ed.). Cotton: origin, history, technology and production. New York: John Wiley \& Sons, 1999. p.23-32.

CRESTE, S.; TULMANN NETO, A.; FIGUEIRA, A. Detection of single sequence repeat polymorphisms in denaturing polyacrylamide sequencing gels by silver staining. Plant Molecular Biology Report, v.19, p.299-306, 2001.

FERREIRA, M.E.; GRATTAPAGLIA, D. Introdução ao uso de marcadores moleculares em análise genética. 3.ed. Brasília: Embrapa-Cenargen, 1998. 220p.

FREIRE, E.C. Distribuição, coleta, uso e preservação das espécies silvestres de algodão no Brasil. Campina Grande: Embrapa-CNPA, 2000. 22p. (Embrapa-CNPA. Documentos, 78).

LACAPE, J.M.; DESSAUW, D.; RAJAB, M.; NOYER, J.L.; HAU, B. Microsatellite diversity in tetraploid Gossypium germplasm: assembling a highly informative genotyping set of cotton SSRs. Molecular Breeding, v.19, p.45-58, 2007.

LEWIS, P.; ZAYKIN, D. Genetic data analysis: computer program for the analysis of allelic data (software). Version 1.0 (d12). Disponível em: $<$ http://alleyun.eebg.uconn.edu/gda/>. Acesso em: 16 jul. 2009.

LIU, S.; CANTRELL, R.G.; MCCARTY, J.C.; STEWART J.M. Simple sequence repeat-based assessment of genetic diversity in cotton race stock accessions. Crop Science, v.40, p.1459-1469, 2000 .

MENEZES, I.P.P. de; HOFFMANN, L.V.; ALVES, M.F.; MORELLO, C. de L.; BARROSO, P.A.V. Distância genética entre linhagens avançadas de germoplasma de algodão com uso de marcadores RAPD e microssatélites. Pesquisa Agropecuária Brasileira, v.43, p.1339-1347, 2008.

NEI, M. Estimation of average heterozygosity and genetic distance from a small number of individuals. Genetics, v.89, p.583-590, 1978.

NEVES, O. da S.; GRIDI-PAPP, I.L.; CAVALERI, P.A.; FERRAZ, C.A.M.; FUZZATO, M.G.; SILVA, N.M. da; SCHMIDT, W.; CORRÊA, D.M. Distribuição geográfica atual dos algodoeiros perenes no Brasil. Primeiro levantamento parcial. Bragantia, v.27, p.437-475, 1968.

NGUYEN, T.B.; GIBAND, M.; BROTTIER, P.; RISTERUCCI, A.M.; LACAPE, J.M. Wide coverage of the tetraploid cotton genome using newly developed microsatellite markers. Theoretical and Applied Genetics, v.109, p.167-175, 2004.

PIRES, C.; SILVEIRA, F.A. da; OLIVEIRA, G.M. de; CARDOSO, C.F.; PEREIRA, F.F.O.; SOUZA, V.V. de; NAKASU, E.Y.T.; PAES, J.S. de O.; TELES, É.; SILVIE, P.; RODRIGUES, S.; MIRANDA, J.; SCOMPARINI, A.; BASTOS, C.; OLIVEIRA, G. dos S.; OLIVEIRA, J.E.; SANTOS, J.B.; BARROSO, P.A.V.; SUJII, E.; FONTES, E. Visitantes florais em espécies cultivadas e não cultivadas de algodoeiro (Gossypium spp.), em diferentes regiões 
do Brasil. Brasília: Embrapa Recursos Genéticos e Biotecnologia, 2006. 38p. (Boletim de Pesquisa e Desenvolvimento, 148).

SCHWENDIMAN, J.; ANO, G.; PERCIVAL, A.E. Cotton collecting in continental Ecuador and Galapagos Islands. Plant Genetic Resources Newsletter, v.64, p.33-37, 1986.

SILVA, E.M.S. Abelhas visitantes florais do algodoeiro Gossypium hirsutum em Quixeramobim e Quixeré, Estado do Ceará, e seus efeitos na qualidade da fibra e semente. 2007. 118p. Tese (Doutorado) - Universidade Federal do Ceará, Fortaleza.

TURCOTTE, E.L.; PERCY, R.G. Genetics of kidney-seed in Gossypium barbadense L. Crop Science, v.30, p.384-386, 1990.
ULLOA, M.; STEWART, J.M.; GARCIA, E.A.; GODOY, S.; GAYTAN, A.; ACOSTA, S. Cotton genetic resources in the western states of Mexico: in situ conservation status and germplasm collection for ex situ preservation. Genetic Resources and Crop Evolution, v.53, p.653-668, 2006.

WEIR, B.S.; COCKERHAM, C.C. Estimating F-statistics for the analysis of population structure. Evolution, v.38, p.1358-1370, 1984.

WESTENGEN, O.T.; HUAMÁN, Z.; HEUN, M. Genetic diversity and geographic pattern in early South American cotton domestication. Theoretical and Applied Genetics, v.110, p.392-402, 2005.

Received on January 3, 2009 and accepted on July 14, 2009 